\title{
Instructional Supervision and the COVID-19 Pandemic: Perspectives From Principals
}

\author{
Jesse D. Brock, EdD \\ Tarleton State University, Stephenville, Texas, United States \\ iD https://orcid.org/oooo-0002-2943-9717 \\ Don M. Beach, PhD \\ Tarleton State University, Stephenville, Texas, United States \\ iD https://orcid.org/ooo-0003-1039-3031
}

Mandy Musselwhite, M.Ed.

Tarleton State University, Stephenville, Texas, United States

Ikie Holder, M.Ed.

Tarleton State University, Stephenville, Texas, United States

Contact: $\underline{s w \text { jbrock@tarleton.edu }}$

\section{Abstract}

Six questions that instructional supervisors have been faced with and had to respond to during the COVID-19 crisis include: (a) How do we support teachers in the transition from face-to-face to virtual classes and meetings; (b) How do we focus on addressing the needs of teachers while engaged in remote or online learning; (c) How do we maintain communication, contact, and relationships with teachers; (d) How do we celebrate successes as teachers work with students in the virtual world; (e) How do we assess the quality of the teaching-learning process; and (f) How do we plan for the next steps? Within the scholar-practitioner theoretical model, this study narrates how two principals in Texas addressed each of these six questions. The case studies presented could be used as historical accounts, meaning that leaders could learn from their successes and their mistakes as they move to the next phase of reopening schools.

Keywords: educational supervision, scholar-practitioner, COVID-19, school leadership

Date Submitted: January 12, 2021 | Date Published: June 25, 2021

\section{Recommended Citation}

Brock, J. D., Beach, D. M., Musselwhite, M., \& Holder, I. (2021). Instructional supervision and the COVID-19 pandemic: Perspectives from principals. Journal of Educational Research and Practice, 11, 168-180.

https://doi.org/10.5590/JERAP.2021.11.1.12

\section{Introduction}

The COVID-19 pandemic has impacted schools across the nation and, although progress has been made with vaccines, schools are still having to balance face-to-face learning with online learning because of the continued dangers to student health. According to the most recent data tracker from the Centers for Disease Control (CDC), over half a million people in the United States have died as a result of the COVID-19 virus (CDC, n.d.). 
The COVID-19 virus continues to impact people's physical health, social and emotional well-being, as well as learning and educational development. Regarding the educational setting, the CDC recently published an executive summary that advised educational leaders and communities to "plan safe delivery of in-person instruction in K-12 schools" (CDC, 2021, para. 1). This message has been modified from the CDC's advice and messages on school operations from one year ago. As early as February 2020 at the onset of the spread of the COVID-19 virus, the CDC warned educational leaders that the COVID-19 virus would drastically impact the operational systems of schools (Lieberman, 2020). Over the spring 2020 semester, schools were forced to make significant changes to the delivery of instruction. As the semester progressed, schools were faced with campus closures as teachers and students were asked to stay home and "shelter in place." According to the National Conference of State Legislatures (2020), "governors and legislatures ... called for the statewide closure of at least 124,000 public schools in 48 states and every U.S. territory” (para. 1).

As a result of the physical closures, schools were tasked with creating online learning experiences for students. It is important to note that the concept of online learning is not new (Singh \& Thurman, 2019). Online learning has been classified as a sub-category under the distance learning umbrella (Stern, n.d.). Distance learning is broadly defined as "an organized instructional program in which teacher and learners are physically separated" (Newby et al., 2000, p. 210). However, online learning specifically refers to "education that takes place over the Internet" (Stern, n.d., para. 3). Schools faced many challenges regarding online learning services, including, but not limited to, low technological literacy among students and faculty, lack of technological resources such as computers and internet, technology-based problems, assessment and evaluation techniques, creating and maintaining support systems (Anderson, 2008). Franklin et al. (2015) noted that while, "online learning currently reaches millions of $\mathrm{K}-12$ learners and its annual growth has been exponential” (p. 1), nothing could have prepared teachers and campus leaders for the rapid transition to all teaching and learning being online.

These challenges were then spotlighted during the physical closure of schools because many educational policies in the K-12 setting fail to keep up with new technologies (Panigrahi et al., 2018; Simpson, 2020). Therefore, it came as no surprise that the challenges and successes varied from state to state and school to school, as schools made the transition from face-to-face learning to online teaching and learning (Abuhammad, 2020; Bansak \& Starr, 2021; Simpson, 2020). Plans for delivering online learning instruction often felt like the process was evolving minute-by-minute. For teachers and supervisors alike, the switch to the new delivery of lessons within a short time frame often proved difficult, not only in the preparation of learning activities and experiences, but in the students' understanding and use of the technology.

The physical closure of schools and subsequent online delivery systems created a critical issue for educational leaders and their role as instructional supervisors. For school leaders, providing instructional supervision in an online learning world proved to be formidable, as such a world required campus leaders "to supervise a vastly different delivery of instruction than schools traditionally offer” (Farley, 2010, p. 7). As educational leaders responded to the physical closing of school campuses for the remainder of the spring 2020 semester, they had to immediately implement moving to an online learning delivery system. For students, some of the most pressing concerns have involved mental and physical health, accessibility to technological devices, accountability associated with completing assignments, and the negative impact on educational attainment and academic outcomes similar to those associated with summer learning loss (Kuhfeld \& Tarasawa, 2020). These concerns not only revealed and widened equity gaps across ethnic groups and socio-economic classes, but also created new gaps within sub-student populations. Scholars and practitioners were worried that the COVID-19 crisis has become "a social crisis that will have long-lasting consequences" (Van Lancker \& Parolin, 2020, p. 243).

Not only have K-12 educational leaders had to learn through experience but have realized that engaging in instructional supervision during what has been called an unprecedented crisis has not been easy. What does 
this crisis mean for instructional supervisors? Instructional supervision, as described by Beach and Reinhartz (2000), is

a complex process that involves working with teachers and other educators in a collegial, collaborative relationship to enhance the quality of teaching and learning within schools. Supervision is contextual ... and supervisors serve as a bridge that supports and sustains efforts, leading to achieving personal and professional objectives. (pp. 8-9)

With that definition as the blueprint for examining practice, the context for this study becomes the exceptional circumstances of the coronavirus pandemic and the movement of instruction to online learning platforms. The process of instructional supervision has become even more complex as instructional leaders work with teachers to move teaching and learning to either a hybrid or totally online learning system within a matter of weeks. It is important to reiterate that the online learning system is not a new phenomenon in the $\mathrm{K}-12$ setting; however, the use of such a system as the single or major form of instruction was a new experience for many schools forced to physically close.

For teachers and students to be successful during the "new normal" created by the COVID pandemic, instructional supervisors needed to have the requisite skills, abilities, and mindset. Renninger (n.d.) has suggested that supervision within a virtual context requires the same skills as supervision in-person, "but with a few added twists" and further noted that a good set of questions can help supervisors focus on the important issues. Farley (2010), in his study of instructional supervision practices in virtual, or what he called cyberschools, found:

(1) There was a lack of structure and disconnect between online teacher criteria and school policy, [but] participants were eager to improve their practices; (2) online instruction presents many challenges to teachers and administrators they may not have experienced throughout their careers; (3) gaps in knowledge of technology were evident showing evidence of teachers with more experience in online instruction than their supervisors; and (4) respondents showed enthusiasm for their jobs and a willingness to improve in an online environment. (p.145-146)

For teachers and students to be successful during the current times and the forthcoming challenge of normality, instructional supervisors need to have the skills, abilities, and mindsets associated with the type of crisis leadership portrayed by Smith \& Riley (2012) and Nevins (2020). The skills, abilities, and mindsets are especially important regarding key, broad decisions relative to teaching and learning. Renninger (n.d.) suggested 11 questions that supervisors should ask employees who were working remotely. Using those questions as a background, we formulated six questions specifically for this study relative to instructional supervisors and the work they had to do during the COVID-19 shutdown of schools. These key questions included: (a) How do we support teachers in the transition from face-to-face to online teaching; (b) How do we focus on addressing the needs of teachers while engaged in online teaching; (c) How do we maintain communication, contact, and relationships with teachers; (d) How do we celebrate successes as teachers work with students in the virtual world; (e) How do we assess the quality of teaching-learning process; and (f) How do we plan for the next steps? The answers to these questions are not readily available in any manual; instead, answers have emerged from a process that includes collaboration, learning from experiences, and conducting critical reflections.

The purpose of this paper was to apply the scholar-practitioner framework to examine the lived experiences of two campus-level instructional leaders and to provide a narrative for how their roles of instructional supervisors addressed each of the questions listed above. Utilizing an autoethnography case study research design (Patton, 2002), each principal individually detailed in his and her own words the lived experiences and provide responses to the previous six questions associated with the impact of COVID-19 on the instructional supervision process. 


\section{Scholar-Practitioner Theoretical Framework}

For the purpose of this study, the scholar-practitioner model (Horn, 2002) was chosen as the guiding theoretical framework. Before describing the core tenants of the theoretical model itself, we should address the following inquiry: What exactly is a scholar-practitioner? Because of various interpretations, "defining the term scholar-practitioner is not necessarily a simple task" (Hebert, 2010, p. 34). In his foundational piece, Horn (2002) claimed, "scholar-practitioners engage in the interplay between theory and practice" (p. 83). Mullen (2003) placed the definition of the scholar-practitioner within an educational leadership context. "The scholar-practitioner," according to Mullen (2003), is an individual "whose engagement in such leadership activity as evaluation, self-reflection, research, and application is aimed at improving schools,” (p. 13) specifically the school in which he or she leads. Therefore, the scholar-practitioner combines the sphere of academic research with the sphere of practice (Bouck, 2011; Godwin \& Meek, 2015). With this skill, the "scholar-practitioner leader situates his or her work in the arena of policy, curriculum development, practical teaching, and authentic assessment" (Lowery, 2016). While agreeing with Lowery's (2016) description, we posit that instructional supervision should be added as an arena in which educational leaders situate their field of practice.

One of the cornerstones of the scholar-practitioner model is reflection (Jenlink, 2006; Horn, 2002; McClintock, 2004; Mullen, 2003). Reflecting on the outcomes from decisions and actions allows educational leaders to conceptualize, grow, learn, and ultimately better lead their organizations into the future. There are two forms of reflection-self and collaborative (Horn, 2002). Focusing on the former, Jenlink (2006) stated that the "purpose of self-reflection, critical and intentional inquiry of practice, is a distinctive and important way of knowing about practice that simultaneously informs practice" (p. 11). While self-reflection has many benefits for a single leader, collaborative reflection allows for the benefits to potentially disperse among several individuals through the process of active exchanges (McClintock, 2004). In all, engaging in reflection and action analysis allows an educational leader to sharpen their tools as craftspeople within their specific trade of school supervision (Hebert, 2010).

\section{Methodology}

\section{Study Context}

As we previously detailed, this paper examines the lived experiences of two campus-level instructional leaders through their responses to six key questions. The principals who participated in this study are currently in their third year of a doctoral program that is a part of the Carnegie Project on the Education Doctorate (CPED) consortium. Their educational training is an important factor, as it directly influences the leadership theory that has impacted their individual approaches to the challenges, barriers, and reforms associated with the COVID-19 response at their schools and across their districts. The doctoral programs in the CPED consortium strive to prepare and train educational leaders to "name, frame, and solve" (CPED, n.d., para. 9) contextual problems based on research literature and experiences gained as educational leaders.

The other two authors were also associated with the CPED doctoral program. One author was a faculty member in the program, and the other was a cohort classmate and a doctoral fellow. As a result, the four authors were able to take part in a collaborative reflection built on their collegial and collaborative relationships within the program.

\section{Research Design}

Utilizing an autoethnography case study research design (Patton, 2002), each principal individually responded in his and her own words to the six key questions that guided the study regarding the supervision of instruction within their respective school settings and the changes due to the COVID-19 pandemic. 
Therefore, this study acted both as a process of qualitative data gathering and collaborative reflection for the two scholar-practitioner principals. The six key questions addressed within this study emerged from a cursory review of the literature and conversations with educators relative to how COVID-19 was impacting teaching and learning in schools. The following sections provide independent narratives from each instructional leader regarding their actions and decisions within the case study context.

\section{Case Study 1-Middle School}

The middle school in this study was a fast-growing campus located west of the Dallas-Fort Worth Metroplex. For the 2019-2020 school year, enrollment was 1,014 students in grades 7 and 8 . The demographics of the middle school are displayed in Table 1.

Table 1: Demographics of Middle School, $(n=1,014)$

\begin{tabular}{lc}
\hline Demographic Category & Percentage of Student-Body \\
\hline Ethnicity & $77.2 \%$ \\
White & $15.8 \%$ \\
Hispanic & $4.3 \%$ \\
Two or More Races & $1.7 \%$ \\
Black & $0.1 \%$ \\
Asian & $0.1 \%$ \\
Native American & \\
Gender & $54.3 \%$ \\
Male & $45.7 \%$ \\
Female & \\
Other & $16.7 \%$ \\
Economically Disadvantaged & $7.4 \%$ \\
Special Education Services & $3.6 \%$ \\
ESL Services & \\
\hline
\end{tabular}

Note. ESL = English Second Language

\section{Timing}

As concerns surrounding COVID-19 began to escalate, an initial closure was announced prior to students being released for spring break 2020. In an abundance of caution, and in line with recommendations of public health officials, students, staff, and families were notified that all campuses would be closed for two additional weeks after spring break. The week of spring break provided district and campus leaders with critically important time for collaboration with surrounding districts and logistical planning. While most suspected that the closure would be brief, all were in agreement that preparations for remote learning were of utmost importance. Instructional leaders began working to develop systems to build teacher capacity for delivering instruction remotely. The key focus for instructional supervisors was building teacher capacity for the new teaching and learning model. 
Brock et al., 2021

\section{Supporting Teachers-Transition}

In the preliminary planning phases, it was evident that the transition from face-to-face, traditional instruction to online, asynchronous learning would be a dramatic shift for teachers, students, and families. Leaders and teachers carefully considered what was needed to meet the needs of the most at-risk student populations, as well as the teachers that would need the most support. District and campus leadership opted to transition in phases: Phase 1 was driven by student choice and aimed toward building teacher and student capacity in online learning platforms; Phase 2 was driven by standards-based instruction and aimed at cementing essential skills for students while supporting teachers through instructional modules.

During Phase 1, students were provided choice boards that included both digital and non-digital activities. The learning tasks were organized by grade level, subject, and difficulty level. Students were encouraged to select activities that covered learning standards that may have been a struggle previously in the year. During this time, teachers were engaged in professional learning activities to build capacity as online learning educators. All teachers completed modules covering learning management systems (LMS), instructional design for online learning, and video conferencing tools. A resource website was also created to provide staff with additional support, and instructional supervisors met with teachers individually as needed.

During Phase 2, special education staff worked closely with general education teams to ensure that accommodations were being implemented. Teachers also established virtual office hours for students who needed assistance. During this time, teachers met with small groups or individual students to provide reteaching, remediation, and intervention. To streamline the process for families, all teachers utilized a standardized lesson planning template. After two weeks of remote learning, families were surveyed, and adjustments were made to both instructional delivery and time commitments.

\section{Meeting the Needs of Teachers}

Early in the process, it became increasingly evident that there were gaps in online teaching skills and that teachers would need a great deal of support to successfully execute online learning. Campus and district leadership categorized the supports needed as technological supports, professional learning supports, and instructional supports. Campus leaders worked with instructional technology staff to provide technical support and with instructional supervisors and instructional coaches to design and provide professional learning and support.

Regarding technological support, connectivity and bandwidth proved to be challenges for some staff members. Therefore, hotspots and internet boosters were provided to staff members in need. Similarly, while all teachers were required to complete introductory professional learning modules, more detailed modules were created at varying levels of proficiency. Instructional supervisors met with individual teachers to discuss their needs, strengths, and weaknesses and collaboratively identified professional learning plans and supports to ensure successful delivery of remote instruction.

Perhaps the most meaningful support was provided through the district's ongoing support and protection of the Collaborative Team Model as part of the Professional Learning Community framework. Prior to the shutdown, teams met at least once per week to plan, analyze data, form intervention and extension groups, or perform other tasks as needed. Meetings were facilitated by team leads and instructional supervisors and supported by campus administrators. While the tasks were significantly different and focused heavily on instructional design and delivery, the structure and protected time were invaluable. Supervisors worked in collaborative teams and teachers were able to divide work, utilize individual strengths, and establish consistency for students. Typically, such teams were limited to the teachers on the campus. However, given the unique and daunting circumstances, many individual teachers formed informal collaborative teams with teachers on other campuses or even in other districts that taught the same subject matter. Instructional 
supervision was bolstered by this collaborative approach and provided invaluable support and prevented feelings of isolation.

\section{Maintaining Communication, Contact, and Relationships}

As the likelihood of returning to campus became less and less of a possibility, instructional leaders made monitoring the well-being and emotional needs of staff a high priority. Monitoring was accomplished through individual check-ins, creating virtual connections, and maintaining frequent communication.

Initially, the principal made personal contact with every staff member through either a phone call or text message. The intent of the communication was to ensure that each staff member was doing well and individual and professional needs were being met and to express appreciation for dedication and commitment as the situation continued to evolve and escalate. After initial contact, the campus leadership team divided the staff into groups and maintained individualized contact on a weekly basis.

The campus leadership team felt that it was imperative to continue to nurture a sense of community among faculty members. To accomplish this, instructional supervisors scheduled virtual weekly meetings. All meetings began with opportunities for teachers to share "Good Things" or affirm others, share information, and solicit feedback. Through Google Forms and private chat features, teachers were also provided opportunities to ask questions, share feedback, or express concerns privately. Supervisors followed up with any teacher directly after the meeting if additional consultation was needed. The goal was to not only maintain community, but also to maintain availability and approachableness.

Lastly, intentional efforts were made to maintain frequent communication. In such a tumultuous time, with an influx of information from national, state, and local officials, instructional leaders wanted to be sure that teachers were aware of and had clarity around the issues. In addition to the weekly meetings, a weekly newsletter was also sent via email.

\section{Celebrating Successes}

Typically, the spring semester brings many opportunities to celebrate the accomplishments and successes of both faculty and students. While the virtual campus looked different, it was important to recognize teachers for the amazing work that was done during both face-to-face and remote learning. A major celebration centered on Teacher Appreciation Week. As a district, we encouraged families to show their support for teachers on social media. Many families independently organized drive-by parades and placed yard signs in teachers' yards to show support. The campus leadership team mailed cards, gift certificates, and notes of affirmation.

It was also important to recognize the accomplishments and milestones from the year. Typically, individual accomplishments such as "Teacher of the Year" and service pins are presented at a yearly awards ceremony. Given the unique circumstances, the presentations were conducted virtually, and the recognitions were then sent out via email and posted to social media pages and the campus website. For teachers who were retiring, socially distanced meetings were scheduled, and gifts were given by the superintendent and campus principal.

\section{Maintaining Quality Instructional Practices}

Despite the unique and rather daunting circumstances, all agreed that high-quality instruction was still a priority. In their role, instructional supervisors and campus leaders sat in on collaborative team meetings and engaged in conversations with teachers to ensure consistency across content areas and grade levels. Just as in face-to-face instruction, during online learning teacher teams were continually assessing student work and designing intervention and extension tasks to cement learning based on curriculum standards. Campus leaders and counselors worked with teachers to support students who were struggling academically or 
becoming disengaged. Teachers, counselors, and instructional leaders met virtually with individual students, small groups of students, and even families to help establish routines and provide individualized support.

\section{Planning for Next Steps}

While successes certainly happened during online classroom teaching and learning, lessons were learned as well. Given the uncertainty and changing recommendations regarding school operations, the campus, with guidance from the district, has already begun working to prepare for a return to face-to-face learning with restrictions, continued online learning, or a hybrid of both face-to-face and online learning. Based on the experiences of the spring 2020 semester, campus leaders know that to be successful they must continue to research successful online learning instructional practices and seek opportunities to build teacher and student capacity. Teachers, students, families, and other stakeholders are being surveyed as to what was beneficial and what could be changed to best support students both academically and socially.

\section{Case Study 2-High School}

Located just south of the Dallas-Fort Worth Metroplex, the high school is the largest high school in the school district. The campus has been steadily growing for the 10 years of its existence. The campus had an enrollment of approximately 1,900 students in grades 9 through 12 for the past school year. See Table 2 for a visual breakdown of the school's demographics.

Table 2: Demographics of High School, $(n=1,900)$

\begin{tabular}{lc}
\hline Demographic Category & Percentage of Student-Body \\
\hline Ethnicity & $65.5 \%$ \\
White & $21.6 \%$ \\
Hispanic & $8.6 \%$ \\
Black & $3.2 \%$ \\
Two or More Races & $0.6 \%$ \\
Asian & $0.4 \%$ \\
Native American & \\
Gender & $51.6 \%$ \\
Male & $48.4 \%$ \\
Female & \\
Other & $32.8 \%$ \\
Economically Disadvantaged & $6.5 \%$ \\
Special Education Services & $3.2 \%$ \\
ESL Services &
\end{tabular}

Note. ESL = English Second Language

\section{Transition}

Due to a calendar that was not in alignment with surrounding school districts, our campus began the spring break holiday a week after the majority of school districts in the area. Therefore, the bulk of the government and agency discussions and decisions occurred while the district's students, faculty, and educational leaders, 
were not in school. While other districts were making decisions with everyone on campus and in class, our district had the benefit of having the educational leadership team working to gather information, have critical discussions, and create potential plans to address the varied possibilities that were presenting with the rising number of COVID-19 cases. These collaborations also led to dialogue between district and campus leaders and teachers to determine their thoughts, concerns, and solutions to transitioning to an online learning model.

Though much effort was focused on ensuring internet access, functioning technology devices and understanding expectations for the students and teachers were also a focus of the transition process. Technology department staff who could be spared from infrastructure tasks became technology teachers and mentors for the classroom teachers. These technology support staff were assigned to individual campuses and charged with finding, creating, sharing, and updating online instruction training with individual instructors and groups of instructors that would make them more confident and successful in shifting their face-to-face teaching to a virtual classroom.

\section{Addressing the Needs}

Campus leaders were required to maintain weekly communications with all of the teachers under their supervision. The meetings occurred individually and in teams, and the purpose of those meetings was to determine the success of the online instruction from the teachers' perspectives as the closest point of interaction with students in this setting. The information gathered from teachers was used to further assess the situation and collaborate on potential updates to the online learning model to ensure the effectiveness for the students. The information was also used by the instructional supervisors as they worked with teachers in their professional learning communities to drive conversations and adapt teaching.

Another aspect of the regular meetings with teachers was to help determine the social and emotional functioning of the staff. The shift to online learning was a dramatic, sometimes problematic, and totally different delivery method for teaching and learning. Because the change to a virtual classroom forced many into learning not only new technologies but new delivery methods as well, the process was unfamiliar and even daunting. Ensuring the well-being of teachers was of critical importance and support was provided through continual reminders in faculty meetings, digital communication, and face-to-face conversations regarding the availability of on-campus and outside counseling sources to assist teachers as needed.

\section{Maintaining Teacher Relationships}

The instructional leadership team created a consistent schedule for communication and meetings in order to minimize the possibility of staff feeling disconnected from others. Part of the initial effort was to utilize the technology platforms to hold weekly digital faculty meetings where the entire faculty could meet. These faculty meetings were used to share critical information and update the faculty with current information related to the pandemic and the shutdown of the district. It also served to allow teachers to see and speak with each other in a safe manner and help them maintain the positive and necessary relationships they had prior to shifting to a virtual environment.

Once the pandemic shifted the learning and separated teachers from the campus, the communication format was adjusted by creating a video channel, which made the sharing and communication of important information similar to face-to-face meetings. Supervisors would engage in conversations with the teachers in the videos, not just disseminate information. By engaging in instructional supervision conversations through the video channel, the teachers felt like they were not just being told information but having authentic conversations. While in-person communication was not possible, this communication model served to give some level of familiarity back to the teachers. 
Brock et al., 2021

\section{Celebrating Successes}

As instructional leaders worked with teachers, many found online learning to be a comfortable model to implement, while others struggled with the adjustment in delivery and structure. Through the transition periods and throughout the remainder of the virtual school year, the instructional supervisors looked for ways to ensure teachers felt valued, necessary, supported, and celebrated by the campus leaders and by the members of the community. During professional and personal conversations with supervisors, teachers shared stories and anecdotal evidence of the tremendous strides the students were achieving while in this unfamiliar learning environment. These stories, while maintaining privacy concerns, were shared throughout the school and community.

The end of the year is a time when most campuses celebrate all teachers with a Teacher Appreciation Week. This year, the instructional leaders worked to maintain many of the traditional celebratory aspects. To accomplish this celebration and maintain health and safety guidelines, the campus leaders organized a drivethrough parade where staff drove by the main entrance of the campus and stopped briefly at the front of the campus. Each teacher received a gift bag that included cards, gift cards, shirts, and snacks. This event provided a brief moment to share a personal thank you with each teacher and to show each one that even though they were not physically on campus, they were cherished. The district encouraged the campuses to honor the Teacher of the Year and give the awards as part of the drive-through celebration.

\section{Quality of Online Learning}

A perpetual concern for all districts has been the effectiveness of the teaching that has occurred in the shift from face-to-face instruction to an online learning model. One concern was the extremely short timeframe for developing and implementing the online model and the lack of understanding of how to adjust when the model was not effective. The instructional leaders knew that the online learning model might be effective for some students and detrimental to others, based on personal preferences, technology reliability, or personal learning characteristics. Therefore, the district adopted a no-harm grading policy that ensured all students' grades would not suffer if students tried to participate and learn. The grading policy coupled with the short development period made it difficult to ascertain the effectiveness of the online learning model. Teachers provided feedback and completed surveys to determine their perspective of the learning process that the district used.

\section{Next Steps}

The district and instructional leaders analyzed the information gathered from the teachers at the conclusion of the year and found that the teachers felt that they were not included enough in the development of the online learning experience that was implemented. With the planning for the beginning of a new school year starting in a virtual platform, the district has partnered with teachers to develop a curriculum that could be adjusted to online delivery, yet could maintain a level of rigor that was developmentally appropriate to challenge the students.

At the same time, state agencies were constantly adjusting the parameters of any district-created distance learning platform to be used in the new school year. The district struggled to make the changes deemed necessary by the teachers while working with the state's shifting guidelines. The district developed a more uniform curriculum and pacing guides to support all teachers with similar lesson activities that allowed for more collaboration by students across classes. In addition, the new protocol allowed for teachers to share ideas around common activities and lessons that could help extend each lesson to ensure rich and high levels of learning. 


\section{Summary}

The case studies presented in this paper highlighted the challenges that the COVID-19 pandemic created for two principals who served as instructional leaders and supervisors within two different districts and at different grade levels. The lived experiences of these principals illustrate the shared involvement and plans of actions that supported teachers during the COVID pandemic, as teachers transitioned from face-to-face instruction to an online teaching-learning platform and subsequent hybrid instructional delivery system for the current year. Their stories illustrate the decisions made and actions taken with regard to the six key questions addressed in this paper. Evident in their narratives are the challenges that instructional supervisors face when working with teachers in the virtual classroom. Like Farley (2010) in his study of instructional supervision practices, the instructional supervisors in this study described similar issues to those faced in "cyberschools." The instructional leaders found that online instruction presented many challenges to teachers and supervisors that each group had not previously encountered. As a result, problem-solving became an essential process as supervisors worked with teachers to deliver online instruction. The instructional supervisors also discovered gaps in knowledge of technology as some teachers were more comfortable than others in moving to an online delivery system. Supervisors, as they worked with teachers in this new instructional setting, found them willing to learn new strategies to improve online teaching and learning so that students could be successful.

Instructional leaders also discovered the importance of community and worked to establish an online community with their teachers. One of the most important lessons learned over the course of the past year has been that schools are social centers of support. As instruction moved from face-to-face learning to an online classroom, instructional leaders had to find ways of communicating with and including faculty in a virtual social network. Equally important was the celebration of successes for both students and teachers. Without personal interactions, the instructional supervisors had to find new ways to support and encourage teachers in the virtual world.

The "lessons learned" in the case studies of the instructional leaders presented here can be used as historical accounts, meaning that leaders could learn from their successes and their mistakes as they move to the next phase of hybrid online instruction or totally face-to-face as they reopen schools. To be successful in the future in the reopening of schools and addressing future crises, instructional leaders must be able to engage in the scholar-practitioner model of critical reflection and analysis to ascertain which strategies worked and which ones did not work within the context of the dramatic changes that occurred on their campuses during the spring 2020 semester. While it is hoped that a crisis such as the one associated with COVID-19 does not reemerge, instructional leaders have to keep in mind that the COVID-19 crisis has yet to conclude and continues to present logistical issues for schools as online instruction continues to be used for some, if not all, teaching and learning. 


\section{References}

Abuhammad, S. (2020). Barriers to distance learning during the COVID-19 outbreak: A qualitative review from parents' perspective. Heliyon, 6(11), e05482. https://doi.org/10.1016/j.heliyon.2020.e05482

Anderson, T. (Ed.).(2008). The theory and practice of online learning. (2nd ed.). Athabasca University Press.

Bansak, C., \& Starr, M. (2021). COVID-19 shocks to education supply: How 200,00o U.S. households dealt with the sudden shift to distance learning. Review of Economics of the Household, 19, 63-90. https://doi.org/10.1007/s11150-020-09540-9

Beach, D. M., \& Reinhartz, J. (2000). Supervisory leadership: Focus on instruction. Allyn \& Bacon.

Bouck, G. M. (2011). Scholar-practitioner identity: A liminal perspective. Scholar-Practitioner Quarterly, 5(2), 201-210.

Carnegie Project on the Education Doctorate. (n.d.). The CPED framework. https://www.cpedinitiative.org/the-framework

Centers for Disease Control and Prevention. (n.d). COVID Data Tracker. https://covid.cdc.gov/covid-datatracker/\#datatracker-home

Centers for Disease Control and Prevention. (2021). Operational Strategy for K-12 Schools through Phased Mitigation. https://www.cdc.gov/coronavirus/2019-ncov/community/schools-childcare/operationstrategy.html

Farley, Gregory C. (2010). Instructional supervision: A descriptive study focusing on the observation and evaluation of teachers in cyberschools (Unpublished doctoral dissertation). Indiana University of Pennsylvania.

Franklin, T. O., Burdette, P., East, T., \& Mellard, D. F. (2015). Differential Access to Online Learning Within and Across Districts: State Education Agency Forum Proceedings Series. (Report No. 8). Lawrence, KS: Center on Online Instruction and Students with Disabilities, University of Kansas. https://kuscholarworks.ku.edu/bitstream/handle/1808/22561/SEA_Topic_8_Summary_July_2015 .pdf? sequence $=1$ \&isAllowed $=\mathrm{y}$

Godwin, M. L., \& Meek, J. W. (2015). The scholar practitioner: Connections of research and practice in the classroom. Teaching Public Administration, 1-16.

Hebert, T. R. (2010). The scholar-practitioner concept and its implications for self-renewal: A doctoral student's perspective. Scholar-Practitioner Quarterly, 4(1), 33-41.

Horn, R. A. (2002). Differing perspectives on the magic of dialogue: Implications for a scholar-practitioner leader. Scholar-Practitioner Quarterly, 1(2), 83-102.

Jenlink, P. (2006). The school leader as bricoleur: Developing scholarly practitioners for our schools. NCPEA Education Leadership Review, 7(2), 54-69. http://files.eric.ed.gov/fulltext/EJ1066733.pdf

Kuhfeld, M., \& Tarasawa, B. (2020). The COVID-19 slide: What summer learning loss can tell us about the potential impact of school closures on student academic achievement [White paper]. The Collaborative for Student Growth at NWEA. https://www.nwea.org/content/uploads/2020/05/Collaborative-Brief_Covid19-Slide-APR20.pdf

Lieberman, M. (2020, February). Schools should prepare for Coronavirus outbreaks, CDC officials warns. EducationWeek. https://www.edweek.org/leadership/schools-should-prepare-for-coronavirusoutbreaks-cdc-officials-warn/2020/02

Lowery, C. L. (2016). The scholar-practitioner ideal: Toward a socially just educational administration for the 21st century. Journal of School Leadership, 26, 34-60. 
McClintock, C. (2004). The scholar-practitioner model. In A. DiStefano, K. E. Rudestam, \& R. J. Silverman (Eds.), Encyclopedia of distributed learning (pp. 393-396). Sage.

Mullen, C. A. (2003). What is a scholar-practitioner? K-12 teachers and administrators respond. ScholarPractitioner Quarterly, 1(4), 9-26.

National Conference of State Legislatures. (2020). Public Education's Response to the Coronavirus (COVID19) Pandemic. https://www.ncsl.org/research/education/public education-response-to-coronaviruscovid-19.aspx

Nevins, M. (2020, March). Leadership in the times of COVID-19. Forbes. https://www.forbes.com/sites/hillennevins/2020/03/19/leadership-in-the-time-of-covid19/\#4516bb6e5e4e

Newby, T. J., Stepich, D. A., Lehman, J. D., \& Russell, J. D. (2000). Instruction technology for teaching and learning. Merrill.

Panigrahi, R., Srivastava, P. R., \& Sharma, D. (2018). Online learning: Adoption, continuance, and learning outcome-A review of literature. International Journal of Information Management, 43, 1-14. https://doi.org/10.1016/j.ijinfomgt.2018.05.005

Patton, M. Q. (2002). Qualitative research \& evaluation methods (3rd ed). Sage.

Renninger, L. (n.d.). 11 high-impact questions managers should ask remote employees. Culture Amp Blog. https:www.cultureamp.com/blog/11-high-impact-questions-managers-should-ask-remote-employees Retrieved 6-15-2020

Simpson, J. C. (2020). Distance learning during the early stage of the COVID-19 pandemic: Examining K-12 students' and parents' experiences and perspectives. Interaction Design and Architecture(s) Journal, lxD\&A(46), 29-46. http://www.mifav.uniroma2.it/inevent/events/idea2010/doc/46 2.pdf

Singh, V., \& Thurman, A. (2019). How many ways can we define online learning? A systematic literature review of definitions of online learning (1988-2018). American Journal of Distance Education, 33(4), 289-306. https://doi.org/10.1080/08923647.2019.1663082

Smith, L., \& Riley, D. (2012). School leadership in times of crisis. School Leadership \& Management, 32(1), 57-71. https://doi.org/10.1080/13632434.2011.614941

Stern, J. (n.d.). Introduction to online teaching and learning. West Los Angeles College. http://www.wlac.edu/online/documents/otl.pdf

Van Lancker, W., \& Parolin, Z. (2020). COVID-19, school closures, and child poverty: A social crisis in the making. Lancet Public Health, 5(5), e243-e244. https://doi.org/10.1016/S2468-2667(20)30084-0

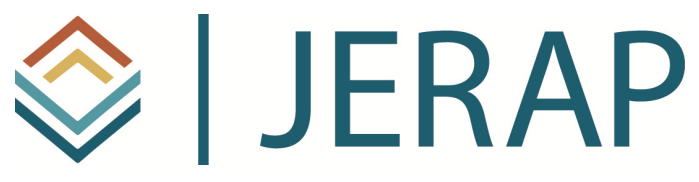

The Journal of Educational Research and Practice is a peerreviewed journal that provides a forum for studies and dialogue about developments and change in the field of education and learning. The journal includes research and related content that examine current relevant educational issues and processes. The aim is to provide readers with knowledge and with strategies to use that knowledge in educational or learning environments. JERAP focuses on education at all levels and in any setting, and includes peer-reviewed research reports, commentaries, book reviews, interviews of prominent individuals, and reports about educational practice. The journal is sponsored by The Richard W. Riley College of Education and Leadership at Walden University, and publication in JERAP is always free to authors and readers. 